\title{
A UTILIZAÇÃO DE VÍDEO E TRILHA COMO INSTRUMENTOS DE EDUCOMUNICAÇÃO NA APA DA UFAM
}

João Felipe Omena Raposo da Câmara ${ }^{1}$

Vilma Terezinha de Araújo Lima²

Resumo: A presente pesquisa avaliou a eficácia do vídeo educativo e da trilha interpretativa como instrumentos de educomunicação. O pano de fundo do trabalho compreendeu a floresta da Universidade Federal do Amazonas (Ufam). A pesquisa foi aplicada com estudantes da própria Ufam e da Escola Estadual Sólon de Lucena. A comparação dos resultados de questionários aplicados antes e depois das atividades, bem como o comportamento e as reações dos alunos durante a pesquisa, indicou que o vídeo teve maior êxito na fixação dos conteúdos, enquanto a trilha foi mais eficaz para sensibilizar os estudantes quanto à necessidade de conservação das áreas florestais. Portanto, constatou-se que o ideal é a utilização de ambos os instrumentos em conjunto.

Palavras-chave: Comunicação; Educação; Educomunicação; Área de Proteção Ambiental.

\footnotetext{
1 Universidade Federal do Amazonas. E-mail: joaofelipecamara@yahoo.com.br

2 Universidade do Estado do Amazonas. E-mail: araujovilma@hotmail.com
}

Revbea, São Paulo, V. 12, № 2: 79-95, 2017.

revista brasileira educação ambiental 


\section{Introdução}

A Universidade Federal do Amazonas está inserida em um dos maiores fragmentos florestais urbanos do planeta, isto é, em aproximadamente 776 hectares. Em 27 de março de 2012, foi criada a "Área de Proteção Ambiental (APA) da Ufam, Inpa, Ulbra, Elisa Miranda, Lagoa do Japiim e Acariquara" (Decreto Municipal $n^{\circ}$ 1.503), que abrange em seus limites a floresta do Campus Universitário. Tal fato passou despercebido entre a comunidade acadêmica, mesmo entre os professores em geral, e também não houve repercussão na imprensa.

É importante, então, que sejam elaboradas estratégias que possam mostrar à comunidade sobre a necessidade de conservação dos fragmentos florestais urbanos, incluindo a APA na qual a Ufam está inserida. Uma das formas de alcançar esse objetivo é por meio da utilização de instrumentos de comunicação com fins educativos, processo chamado de "educomunicação". Ele consiste na mudança de uma estrutura hierarquizada entre professor e alunos, centrada primordialmente nos livros e na sala da aula, para uma estrutura mais democrática e participativa, em que os instrumentos de comunicação fazem parte do contexto educacional e os próprios estudantes têm papel importante na produção elou aplicação prática dos conteúdos. As estratégias educacionais incluem o uso de novas tecnologias de comunicação e informação. Elas devem ser baseadas na realidade vivenciada pelos educandos, considerando aspectos como o meio em que vivem, a linguagem utilizada e os seus hábitos e costumes. Como exemplo desses instrumentos, citam-se 0 vídeo ${ }^{3}$ e a trilha educativa produzidos pela equipe do Centro de Ciências do Ambiente (CCA) da Ufam para o Projeto Curupira $\mathrm{II}^{4}$, cuja verificação da eficácia como instrumentos de educomunicação é o objetivo geral desta pesquisa.

\section{Educomunicação}

Educação e comunicação são dois conceitos interdependentes. É impossível educar sem que haja a produção de mensagens orais, escritas ou por sinais. Da mesma maneira, é improvável comunicar-se sem que os interlocutores sejam educados para isso. De acordo com Freire (1996 p. 23): "Não existe docência sem discência [...] Quem ensina aprende ao ensinar e quem aprende ensina ao aprender". Kunsch (1986, p. 6) estabelece que "Toda atividade comunicativa é uma atividade educativa e vice-versa". No processo de ensino, tanto educador quanto educando devem utilizar-se de códigos comuns a ambos para trocar mensagens, expor pontos de vistas e chegar a

\footnotetext{
${ }^{3}$ Disponível em https://vimeo.com/103954454

${ }_{4}$ Projeto realizado pelo Centro de Ciências do Ambiente (CCA) da Ufam, com recursos do Programa de Apoio à Popularização da Ciência, Tecnologia e Inovação (POP C, T\&l) da Fundação de Amparo à Pesquisa do Amazonas (Fapeam). O projeto tem como objetivo a popularização do conhecimento científico sobre a APA da Ufam por meio de instrumentos educativos como o vídeo, a trilha interpretativa e jogos educativos.
}

Revbea, São Paulo, V. 12, № 2: 79-95, 2017. 
novas conclusões, fazendo assim uma reforma no pensamento. Ao dizer isso, a autora confirma que o processo da educação se assemelha ao da comunicação, pois é necessário que haja um emissor e um receptor, que interagem entre si, trocando mensagens e emitindo feedbacks que levarão ambas as partes a novas conclusões. A reciprocidade do processo faz com que emissor e receptor constantemente alternem seus papéis no processo educação/comunicação. Goergen (1986) ratifica a ideia ao afirmar que ensino e aprendizagem são duas etapas de um mesmo processo e que não mais devemos usar os termos emissor e receptor no processo comunicativoeducativo, mas sim o termo "participantes".

Nas últimas décadas, o avanço das novas tecnologias e o barateamento de aparelhos usados para produzir e disseminar informações promoveram mudanças tanto no modo de se comunicar como no modo de aprender dos mais jovens. Para Citelli (2011, p.65), a comunicação desempenha papel crucial nos processos educativos atuais. O autor assegura que "há um gigantesco movimento no interior do qual a comunicação, em suas múltiplas formas, conceitos, manifestações, passa a desempenhar papel de centralidade, de lócus estratégico".

O modelo educacional hegemônico vigente na maioria das escolas do Brasil, baseado na relação hierárquica entre professores e estudantes e restrito ao interior das salas de aula, está ficando ultrapassado e insuficiente para jovens criados nesse contexto educacional no qual os próprios jovens desempenham papel de produtores de conteúdos e em que a comunicação é constante e instantânea. Nesse cenário, o papel de estudantes como meros "depositores do conhecimento" não é mais eficaz.

Segundo Martín-Barbero (2011), a interação com novas tecnologias de informação faz parte do modo de comunicar e aprender dos mais jovens. O "ecossistema comunicativo", ou melhor, "toda a forma de comunicação presente nos dispositivos midiáticos no entorno dos jovens" (MARTíNBARBERO apud SOARES, 2011, p.43), pede alternativas mais dinâmicas e democráticas para o ensino, assim como o estabelecimento de um contexto no qual tecnologias de comunicação e expressão produzidas pelos próprios estudantes façam parte do processo educativo. Se não produzidas pelos jovens, tais tecnologias devem se aproximar da realidade, da linguagem e do contexto em que eles estão inseridos. Já Orozco-Gómez (2011, p.160) assevera que não é mais possível "prescindir de novas tecnologias de comunicação para a educação".

É necessário, portanto, uma mudança nas práticas educativas, a fim de que estas estejam adequadas à realidade desses jovens. A utilização de instrumentos e estratégias de comunicação na educação, produzidos com a participação dos próprios educandos e respeitando as especificidades desse público, recebe o nome de Educomunicação.

O documento do Programa Nacional para a Educação Ambiental ProNEA (2008) classifica a Educomunicação como "o Processo de 
comunicação com intencionalidade educacional expressa e que envolve a democratização da produção e de gestão da informação nos meios de comunicação em seus diversos formatos, ou na comunicação presencial" (BRASIL, 2008, p.8). Segundo Soares (2011, p.15), a educomunicação "designa um campo de ação emergente na interface entre os tradicionais campos de educação e da comunicação". Já Citelli e Costa $(2011$, p.8) a concebem "como uma área que busca pensar, pesquisar, trabalhar a educação formal, informal e não formal no interior do ecossistema comunicativo". Esses autores reforçam a ideia de que a educomunicação vai além da utilização de instrumentos no processo educativo, mas sim que ela se configura como um modelo de ensino e aprendizado no qual a comunicação e os próprios educandos desempenham papel central, não sendo estes mais somente receptores, porém também produtores de conteúdos. A educomunicação propõe a utilização de variados meios para o intercâmbio de mensagens no processo educativo. Na educação formal, em geral, os instrumentos de comunicação utilizados são os livros, a lousa e a voz do professor. São processos nos quais os estudantes não têm participação em sua produção e com frequência ignoram as realidades social e regional dos discentes.

Tal modelo de educação/comunicação é o oposto da "educação bancária", expressão criada por Freire (1996). Em processos unilaterais de educação, uma das formas de avaliar se a mensagem foi de fato assimilada pelo receptor como deveria ser é fazer com que este retorne a mensagem ao emissor (retroalimentação) conforme sua compreensão. Esse ultrapassado modelo de comunicação, segundo Wohlgemuth (2005, p.12), tem origem militar na Segunda Guerra Mundial, pois era preciso certificar que as mensagens de planos de ataque foram perfeitamente entendidas para evitar equívocos. Portanto, exigiam apenas confirmação de compreensão da ordem dada sem espaço para reflexão ou discussão.

Existem inúmeros instrumentos que podem ser utilizados como ferramentas de educomunicação, como cartilhas, rádio, manuais, jogos, aplicativos para celular, conteúdos on-line entre outras formas. Tais instrumentos fazem parte do "ecossistema comunicativo", de uma geração que desde os primeiros anos de vida já estava intimamente ligada às novas tecnologias da informação (MARTíN-BARBERO, 2011, p.125). A elaboração desses instrumentos de educomunicação "requer uma racionalidade estruturante: exige clareza, planejamento, acompanhamento e avaliação" (SOARES, 2011, p.37). Segundo o autor, como em qualquer forma de educação, não existem fórmulas prontas para tal processo. Os instrumentos e ações educacionais devem tanto ser próximos da realidade local como ser apresentados de uma forma que desperte e prenda a atenção dos educandos. Assim, devem se levar em consideração aspectos socioeconômicos e culturais do público ao qual o instrumento será dirigido, tais como: escolaridade, faixa etária, possibilidades de expressão daquele público, entre outros aspectos locais para somente então determinar qual estratégia a ser usada para a educomunicação. (SOARES 2011, p.14) 
Levando essas características da educomunicação em conta e com o objetivo de oferecer informações aos estudantes sobre a APA da Ufam, foram elaborados dois instrumentos pelo Centro de Ciências do Ambiente (CCA): o vídeo educativo e a trilha interpretativa. Os instrumentos tiveram sua eficácia educomunicacional avaliada, o que constitui o objetivo de estudo principal desta pesquisa.

\section{Vídeo educativo}

O vídeo é um instrumento de comunicação que auxilia na fixação das mensagens e na percepção da realidade. Wohlgemuth (2005, p.12) afirma que "Como a percepção do ser humano sobre o mundo exterior é proveniente, em grande parte, da visão e da audição, as mensagens audiovisuais possuem uma enorme capacidade de transmissão de conteúdos". Os vídeos permitem também que o telespectador veja entrevistas, depoimentos, imagens de acervo, fatos históricos, entre outros itens que podem tornar a experiência ainda mais rica em conhecimento.

Atualmente, a utilização de vídeo com fins educativos está mais acessível a professores e mesmo aos estudantes, que podem utilizar essa ferramenta para troca de informações necessárias ao processo educativo, tornando-o assim mais adequado às necessidades de comunicação de um grupo que "se utiliza muito dos estímulos visuais e que cresceu como uma geração multimídia, e, portanto, espera que o vídeo faça parte de suas experiências educacionais" (TELG,1999, p.1).

O uso desse meio como instrumento de educomunicação faz parte daquilo que o autor chama de "pedagogia audiovisual". Além disso, ele independe das condições climáticas para ser apresentado, bem como não exige deslocamento das turmas para aplicação: pode ser aplicado nas próprias salas de aula da universidade ou levado às escolas. Outra característica dele é poder inserir elementos que estão distantes como, por exemplo, os depoimentos de especialistas, gráficos, elementos históricos, as comparações etc.

A equipe de professores do CCA produziu o roteiro do vídeo do Projeto Curupira II. Assim, ela definiu como tema principal do conteúdo dos instrumentos a APA da Ufam, com foco principal nos aspectos botânicos do fragmento florestal. Por conta disso, selecionaram-se espécies vegetais presentes na floresta para serem enfatizadas no vídeo e, ainda, escolheram-se professores da própria Ufam para a gravação de depoimentos. Algumas

\footnotetext{
5 A pedagogia audiovisual "é uma metodologia de informação, educação e capacitação popular estruturada a partir das características de linguagem audiovisual e criada para o desenvolvimento sustentável no campo e na cidade. Faz uso de sistemas de produção e reprodução de mensagens, optando pelo vídeo: um instrumento adequado, econômico, flexível e versátil que oferece grande autonomia no processo de produção de mensagens" (WOHLGEMUTH, 2005, p.12)
} 
atividades educacionais realizadas na APA também foram destacadas no vídeo.

Vale ressaltar, no entanto, um aspecto negativo do uso de vídeos. Uma das barreiras que dificultam a assimilação e a compreensão dos conteúdos apresentado por meio deles é a passividade que geram na audiência, que assiste a videoaula da mesma forma que a um programa de televisão. Romper com essa passividade é fundamental para que o aluno assimile e reflita sobre 0 conteúdo apresentado (RAMOS s.d., p. 7). Cabe ao educador, portanto, encontrar formas de superar esse comodismo, seja promovendo o debate a respeito do conteúdo, utilizando práticas educomunicacionais complementares, seja adotando outras estratégias conforme o contexto.

\section{Trilha interpretativa}

Para romper a passividade e aproximar os espectadores do conteúdo apresentado, foi criada uma trilha interpretativa. Segundo Kunsch (2003, p.186), trata-se de um instrumento de comunicação dirigida aproximativa caracterizado pela presença física e pelo contato direto e pessoal dos públicos com a organização (ou objeto do estudo), sendo, portanto, uma comunicação interativa e presencial. As visitas dirigidas exigem que o trajeto da trilha e o público sejam determinados previamente, além da presença de guias treinados para conduzir e acompanhar os estudantes (FORTES, 2003, p.335). O percurso da trilha deve ser curto, mas rico em elementos naturais. Seus objetivos são familiarizar os estudantes com os elementos naturais e promover a "interação entre pessoa e paisagem para despertar nos estudantes valores relacionados à proteção e sensibilização ambiental' (GUIMARÃES, 2006, s.p.). E é interpretativa quando possibilita "uma tradução da linguagem da natureza para a linguagem comum das pessoas, fazendo com que percebam um mundo que nunca tinham visto antes" (SANTOS et al, 2011, p.191). Menghini (2005, p.43) afirma que as trilhas interpretativas "têm o propósito de estimular os grupos de atores a um novo campo de percepções, com o objetivo de levá-los a observar, questionar, experimentar, sentir e descobrir os vários sentidos e significados relacionados ao tema selecionado". Guimarães (2006, s.p.) explica que não somente a multiplicidade de estímulos sensoriais é importante para o aprendizado na trilha, mas também a curiosidade e os questionamentos que a atividade pode proporcionar.

Quanto ao aspecto educacional das trilhas, Martín-Barbero (2011, p.126) diz que o processo educacional não deve se restringir ao ambiente de sala de aula, pois o conhecimento é "disperso e fragmentado e pode circular fora dos lugares sagrados nos quais estavam". Boff (2012) defende que a educação para a sustentabilidade deve ser feita promovendo o contato do estudante com o meio ambiente que o circunda, sem se restringir à sala de aula. A atividade da trilha interpretativa no Projeto Curupira II teve o objetivo de corroborar as ideias dos dois autores, isto é, proporcionar aos estudantes a 
oportunidade de aprendizado fora do local tradicional do ensino, em contato direto com os elementos que serão estudados.

Fritzen (2010) e Matarezi (2006) confirmam que há certo distanciamento das questões ambientais por parte dos jovens que desde a infância vivem exclusivamente em ambientes urbanos. Matarezi (2006) assevera que esse distanciamento pode levar à perda da consciência ambiental desses jovens e que por isso mesmo é necessário que eles tenham algum tipo de "toque" com a natureza a fim de recuperar essa consciência perdida. Para isso, é necessário que haja, dentro das cidades, espaços que permitem esse contato. Já para Fritzen, (2010) a conservação e a realização de atividades educativas nesses espaços possibilitam a sensibilização a respeito da multiplicidade de aspectos que tais área possuem. Ainda nesse sentido, Guimarães (2006) afirma que atividades em espaços como esses podem desenvolver nos jovens a consciência ambiental que se encontra fragilizada devido ao estilo de vida urbano da maioria deles.

Ao se elaborar instrumentos de educomunicação, uma série de fatores, tais como inadequação do meio ou da linguagem utilizada, inaplicabilidade do instrumento e até mesmo dificuldades técnicas, pode fazer com que o objetivo da comunicação não seja alcançado. Portanto, o presente trabalho se justifica pela necessidade de se avaliar a eficácia do vídeo e da trilha escolhidos e utilizados como instrumentos de educomunicação na APA da Ufam.

\section{Procedimentos metodológicos}

Uma vez que o objetivo principal da pesquisa foi avaliar o vídeo e a trilha como instrumentos de educomunicação, a participação do pesquisador durante o processo de criação e produção de ambos os instrumentos junto à equipe do CCA foi necessária para o melhor entendimento de cada etapa, desde a produção deles à aplicação da pesquisa. Assim, foram definidos o conteúdo do vídeo e criado o roteiro, em seguida foi contratada uma equipe de produção. Após isso, ocorreram discussões a respeito do percurso e do conteúdo a ser focado na trilha interpretativa, com base nas informações apresentadas no vídeo. Já existia o caminho na mata, os pesquisadores identificaram espécies e nas paradas programadas eram explicadas as características das plantas.

Houve também a produção de folders por meio do Programa de Atividade Curricular de Extensão (PACE) - que contou com o apoio das alunas do curso de Relações Públicas -, a fim de serem distribuídas aos participantes da atividade na trilha instruções de segurança e informações sobre espécies da flora mostrados no vídeo e que se encontram ali presentes. O objetivo desse instrumento foi complementar os conhecimentos passados pelo guia ao longo do percurso.

Uma vez prontos os instrumentos de educomunicação a serem utilizados na pesquisa, a próxima etapa foi a aplicação e avaliação de sua eficácia. Para isso, realizaram-se pesquisas com estudantes da Ufam e de uma

revista brasileira educação ambiental 
escola da rede estadual de ensino de Manaus. O objetivo inicial era que mais turmas de escolas de ensino médio da capital do Amazonas participassem da atividade na trilha e da exibição do vídeo, no entanto, questões burocráticas referentes ao transporte de estudantes para o Campus e a demora na finalização do vídeo impossibilitaram a realização da pesquisa com um número maior de turmas.

A avaliação do vídeo se deu da seguinte forma: os estudantes responderam a um questionário com perguntas fechadas sobre a APA da Ufam, em seguida assistiram ao vídeo e, por fim, responderam novamente o questionário para que fosse feita a comparação dos resultados de ambos. A diferença entre a quantidade de respostas certas e erradas dadas antes e após os estudantes serem submetidos aos instrumentos de educomunicação consistiu na resposta para o objeto de estudo da presente pesquisa.

Adotou-se o mesmo questionário para ambos os instrumentos. Ele foi produzido a partir de informações contidas no vídeo educativo e era dividido em duas partes: a primeira, intitulada "Questionário APA", era composta por três questões fechadas relacionadas à APA, sendo que a segunda e a terceira questões pediam para que os alunos que as respondessem de forma positiva especificassem como ficaram sabendo da criação da APA e quais atividades ali realizaram, respectivamente. Essa primeira parte só estava disponível no questionário aplicado antes da exibição do vídeo ou realização da trilha, visto que não havia necessidade de comparação das perguntas. A segunda parte era intitulada "Questionário vídeo" e possuía dez questões sobre o conteúdo do vídeo (ou da trilha, já que as informações disponíveis em ambos eram similares). Era recomendado que os alunos respondessem as questões que soubessem e deixassem em branco aquelas que não soubessem, pois a marcação aleatória de respostas poderia interferir no resultado da pesquisa. No fim do questionário aplicado após a exibição do vídeo ou a realização da trilha, havia uma pergunta na qual os estudantes respondiam se haviam aprendido muito, aprendido pouco ou se simplesmente não haviam aprendido com os instrumentos.

No total, 227 alunos de diferentes cursos da universidade participaram dessa etapa da pesquisa. Foram escolhidas de maneira aleatória turmas de cursos de diferentes áreas do conhecimento, cujas aulas são realizadas nos Setores Norte e Sul do Campus Universitário. Solicitou-se aos professores que cedessem parte de seus horários de aulas para a aplicação da pesquisa, da qual participaram as turmas cujos professores aceitaram em ceder parte de suas aulas para a aplicação.

Alguns aspectos foram observados e anotados durante a realização da atividade na trilha: as perguntas e observações que os alunos faziam, comentários entre os colegas, itens que chamavam atenção dos alunos além daqueles destacados na trilha e no folder e, também, o interesse demonstrado ao longo da atividade. Tais dados, assim como aqueles que foram observados durante a apresentação do vídeo, constituem elementos secundários para a 
obtenção dos dados que serviram de base para a avaliação dos resultados da pesquisa.

A pesquisa apoiou-se na abordagem qualitativa, pois buscou analisar a eficácia dos instrumentos como ferramentas da educomunicação, algo que não pode ser quantificado. Mesmo que se tenha analisado o quanto os estudantes sabem a respeito do assunto, o presente empreendimento não se tratou de uma pesquisa quantitativa, visto que não se buscou determinar quantos daquele universo sabem e quantos não sabem sobre o tema, mas sim buscar uma ideia geral, uma tendência sobre o saber relacionado à unidade de conservação. E esse é um dos objetivos da pesquisa qualitativa, conforme afirma Triviños (2001, p.83): "A pesquisa qualitativa pretende apenas obter generalidades, ideias predominantes, tendências que aparecem mais definidas entre as pessoas que participam do estudo".

Parte do trabalho foi baseada em pesquisas bibliográficas sobre temas relacionados às unidades de conservação, produção de vídeo e educomunicação. Também foram feitas entrevistas com pessoas que atuam diretamente com o tema investigado e a análise de documentos a respeito da APA da Ufam e das unidades de conservação de Manaus. A metodologia adotada para avaliar o conhecimento adquirido pelos estudantes com a utilização dos instrumentos de educomunicação foi a pesquisa-ação, que segundo Engel:

...é um tipo de pesquisa participante e participante engajada, em oposição à pesquisa tradicional, que é considerada como independente não reativa e objetiva. Como o próprio nome já diz, a pesquisa-ação procura unir a pesquisa à ação ou prática, isto é, desenvolver o conhecimento e a compreensão como parte da prática (ENGEL, 2000, p. 82).

Por ser "participante", compreende-se que na pesquisa-ação o pesquisador deverá pôr em prática elementos que vão interferir na realidade a ser pesquisada. Tal autor afirma ainda que essa pesquisa é amplamente utilizada para fins educativos, pois "possibilitava avaliar empiricamente o resultado de crenças e práticas em sala de aula". (Idem). Trazendo para essa pesquisa, a exibição do vídeo e a participação na trilha consistem nos fatores que vão interferir na realidade do conhecimento dos alunos.

\section{Resultados e discussões}

De uma forma geral, pode-se constatar que o vídeo melhorou de forma significativa a quantidade de respostas certas no questionário, uma vez que antes da exibição do vídeo apenas 503 respostas certas (20\%) foram dadas. Após serem submetidos a ele, os estudantes acertaram 1774 (70\%). A diferença na quantidade de respostas certas dadas pelos estudantes antes e depois da exibição do vídeo mostra que este é sim uma ferramenta eficaz na disseminação de conteúdos ambientais para os estudantes.

revista brasileira educação ambiental 
Os alunos do curso de Engenharia Civil foram os que menos acertaram em percentual antes da exibição do vídeo: apenas 15\% das questões (90 respostas) foram respondidas corretamente, enquanto os alunos do curso de Ciências Biológicas e de uma turma composta por estudantes de diversos cursos (Engenharia de pesca, florestal e Agronomia) acertaram 40\% das questões postas antes da exibição do vídeo.

O melhor aproveitamento em cursos após a exibição de vídeo novamente ficou com os alunos de Ciências Biológicas, com $87 \%$ das perguntas respondidas corretamente (122 respostas). Isso se deve ao fato de nesse curso os estudantes já estudarem assuntos relacionados à flora, o que não ocorre em outros cursos pesquisados. O curso cujos alunos obtiveram a melhora mais significativa após a exibição do vídeo foi Engenharia de Materiais, com aproveitamento das questões aumentado de 19\% para $74 \%$.

Dos 255 alunos que participaram da pesquisa, 203 afirmaram que, de acordo com as suas próprias opiniões, aprenderam muito com o vídeo, o que representa $80 \%$ do total de respostas (Gráfico 1). Já 47 (18\%) disseram ter aprendido pouco, mas ainda assim aprenderam algo, enquanto os que afirmaram que não aprenderam nada com o vídeo somam $2 \%$ do total pesquisado (4 estudantes).

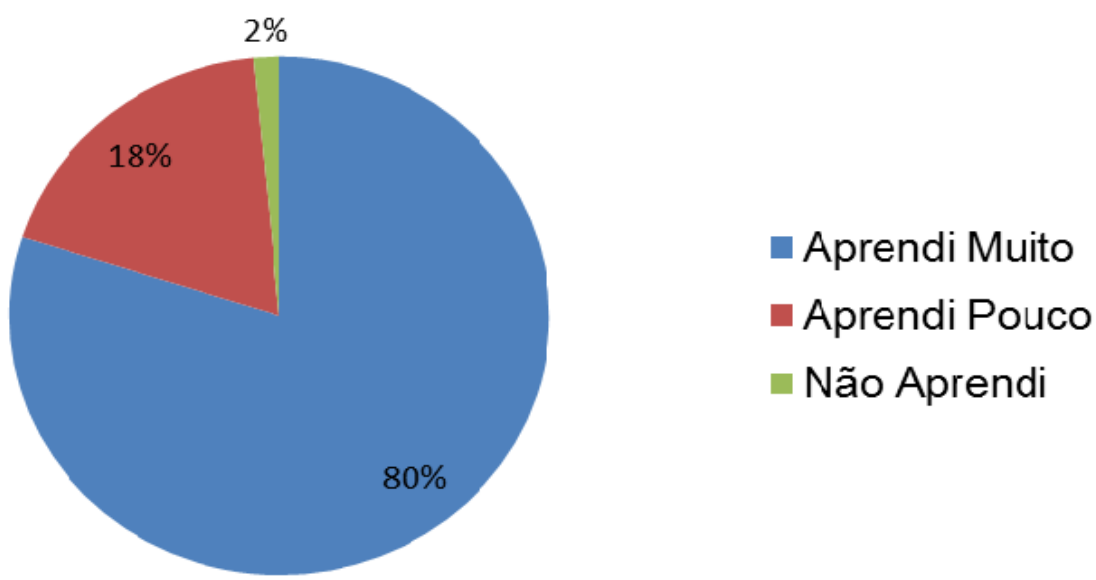

Gráfico 1: Aprendizado adquirido com o vídeo Fonte: Dados de campo.

Alguns detalhes do comportamento dos estudantes e comentários sobre o vídeo foram observados durante as apresentações e anotados para constar como parte da pesquisa:

- No geral, os alunos se mostraram interessados pelo vídeo e seu conteúdo e elogiaram com frequência a beleza das imagens captadas e dos desenhos feitos para a exibição, bem como a qualidade do trabalho realizado pela equipe de produção. 
- Nenhum aluno se evadiu da sala durante a apresentação do vídeo e poucos foram os que mostraram desinteresse ou sono.

- Os alunos do curso de Relações Públicas se mostraram interessados não somente pelas informações ambientais contidas no vídeo, mas também questionaram sobre a produção dele e dos instrumentos de comunicação utilizados na atividade. Também se mostraram interessados em participar da trilha guiada.

- Os alunos do curso de Engenharia Mecânica ficaram, após a exibição do vídeo, fazendo perguntas sobre a produção, que afirmaram ser um dos pontos altos do vídeo. Segundo um dos estudantes, as imagens e a sequência das informações despertam a atenção dos estudantes e facilitam a assimilação do conteúdo. Um estudante também disse que o vídeo, apesar de não abordar um assunto com o qual ele tinha contato ou interesse, conseguiu apresentar informações úteis sem ser monótono.

- Os alunos do curso de Engenharia Civil demonstraram interesse em participar de atividades guiadas na trilha, por conta do convite mencionado no fim do vídeo. Explicaram que não participam desse tipo de atividades no seu curso, por isso achariam interessante aproveitar a oportunidade.

- Após a apresentação do vídeo (Figura 1) e aplicação de questionários, os alunos da turma de Geologia disseram que tanto o vídeo como a trilha poderiam ter uma abordagem focada não tão somente na parte botânica, mas também deveria trazer aspectos geológicos da floresta da Ufam. Esse fato, no entanto, não fez com que os alunos perdessem o interesse no vídeo. Pelo contrário, eles sugeriram a criação do projeto Curupira III, abordando esses aspectos, e também que algum aluno de Geologia poderia participar da trilha como guia, passando informações sobre tais aspectos para os visitantes. Os estudantes afirmaram ainda que as aulas práticas realizadas na floresta da Ufam, além de mostrarem em campo aquilo que eles aprendem em teoria na sala de aula, servem para aproximar os alunos da floresta, ressaltando a importância da manutenção dos fragmentos florestais dentro das cidades, assim como consistir em diferencial turístico dessas áreas, que poderia ser aproveitado melhor em nossa cidade.

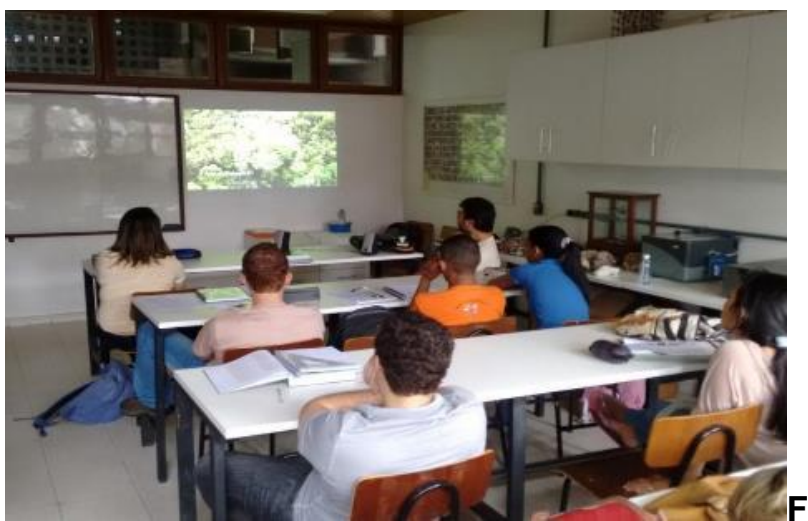

Figura 1: Exibição do vídeo para alunos do curso de Geologia.

Fonte: Dados de campo. 
- Alunos do curso de Ciências Biológicas contaram que participaram de atividades na APA, como aulas práticas, e ressaltaram que a utilização do vídeo para a educação de estudantes que estão distantes dos fragmentos florestais é importante, já que pode levá-los a conhecer, mesmo que pela tela, como é o interior da floresta. Além disso, eles demonstraram empolgação ao ver seus colegas de sala no vídeo.

- É importante destacar que o questionário foi aplicado logo após a apresentação do vídeo. Caso fosse aplicado meses após a exibição, os resultados poderiam ser diferentes. Para que as informações adquiridas não se dissipem do arcabouço de conhecimento dos alunos, é recomendado que se utilizem outros instrumentos (como a trilha) para auxiliar na assimilação do conhecimento adquirido com o instrumento.

Já a pesquisa na triha foi realizada com 32 alunos do segundo ano do Ensino Médio de uma escola da rede estadual de ensino da cidade de Manaus na manhã do dia 5 de novembro de 2014. Assim como na atividade com o vídeo, os alunos responderam o questionário antes e depois de participarem da atividade na trilha e receberam um folder com orientações para a atividade e com informações sobre os hábitos de crescimentos e espécies de vegetais presentes na floresta da Ufam. Os estudantes se mostraram interessados, fazendo perguntas tanto sobre os aspectos botânicos, abordados no folder, assim como sobre outros aspectos, entre eles o relevo da área, as frutas e até mesmo sobre a sobrevivência na selva, além de tirarem muitas fotos estilo selfies para postarem nas redes sociais. Tal fato denota a necessidade que eles possuem de compartilhar com os amigos momentos interessantes. No caso, uma atividade na trilha é algo pouco usual para esses jovens, o que acaba por gerar inúmeras curtidas e comentários em suas páginas.

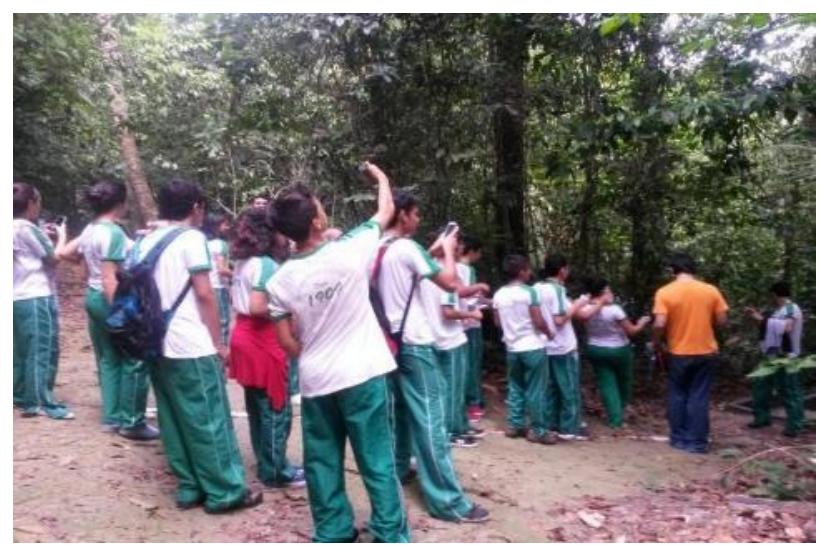

Figura 2: Alunos tirando selfies em atividades na trilha da Ufam.

Fonte: Dados de campo. 
Antes da atividade na trilha, os alunos acertaram $20 \%$ das perguntas do questionário (65 de 320 questões). Após a atividade, o aproveitamento subiu para 39\% (126 de 320). Apesar do aumento de quase 50\% na quantidade de acertos após a realização da atividade na trilha, o número de respostas erradas continuou alto (61\%). Apesar disso, a porcentagem de alunos que responderam ter aprendido com as atividades realizadas foi maior entre os que participaram da trilha: $91 \%$ (29 alunos) afirmaram que aprenderam muito com a atividade, enquanto somente $82 \%$ (23) disseram ter aprendido pouco (Gráfico 2).

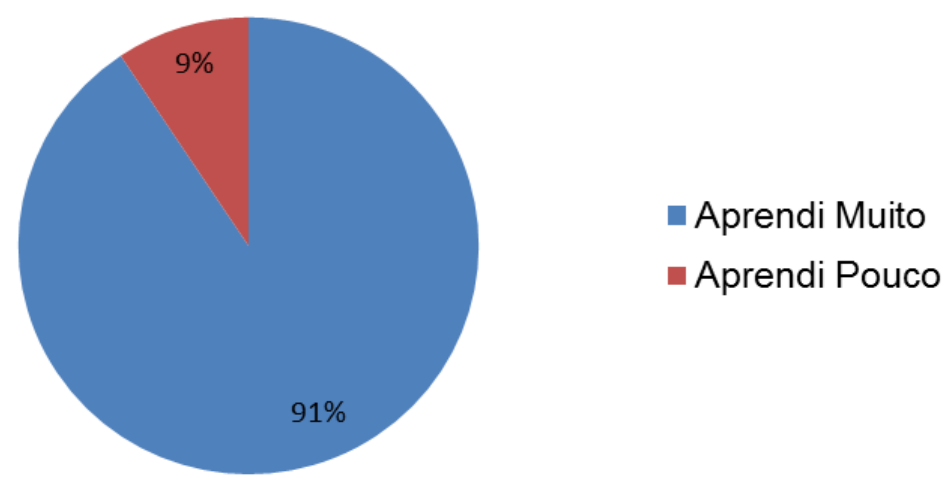

Gráfico 2: Aprendizado adquirido com a atividade na trilha Fonte: Dados de campo.

Foram observados, também, assim como na exibição do vídeo, alguns aspectos dos comportamentos dos estudantes que participaram da trilha:

- Os alunos se mostraram interessados nas espécies botânicas destacadas na atividade. No entanto, frequentemente perguntavam se veriam animais ao longo da trilha, o que demonstra que a fauna também desperta interesse nos estudantes.

- Eram frequentes as reclamações relativas ao calor e às picadas de mosquitos. Porém, os estudantes demostravam estar à vontade e tranquilos durante a realização da atividade.

- Além da flora e da fauna, outro ponto comentado pelos alunos foi o relevo, principalmente nas áreas próximas ao barranco em que está situada a escada, assim como já no fim da trilha, na subida final.

- Foi notado e perguntado o motivo da diferença entre a área nativa e a floresta secundária no fim da trilha, na área que antigamente era a fazenda experimental da Ufam, e que atualmente está reflorestada.

Os resultados dessa pesquisa serão utilizados futuramente para a elaboração de estratégias de educação ambiental no Campus. 


\section{Conclusões}

A pesquisa permitiu avaliar o vídeo e a trilha como instrumentos de educomunicação na APA da Ufam. O documento do ProNEA (2008) afirma que as ações de educomunicação podem ser utilizadas em universidade e escolas para promover o conhecimento em um contexto "biorregional e local bem definido", o que ocorreu neste caso. A utilização dessas ferramentas em atividades que estimulam a participação ativa dos estudantes, estejam eles inseridos no interior da APA ou vendo um vídeo que desperte para a realidade no seu entorno, é eficaz no processo de educação para a conservação daquele espaço. Tais instrumentos abarcam todas as características da educomunicação socioambiental, e não somente aquela restrita às salas de aula, e por isso obtiveram resultados satisfatórios.

A produção dos instrumentos, o vídeo e a trilha, foi feita por uma equipe especializada e levando em consideração o perfil do público alcançado pela atividade. Esse fator é fundamental para que os estudantes se mantivessem interessados durante toda a exibição do vídeo e a realização da atividade na trilha. A linguagem dos instrumentos, por exemplo, apesar de didática, era simples, acessível a estudantes de diversos cursos da Universidade e do Ensino Médio. As imagens do vídeo e as experiências sensoriais da trilha fizeram com que o público se mantivesse atraído do início ao fim da exibição/realização. No entanto, alguns alunos e professores de alguns cursos sentiram falta de conteúdos referentes às suas áreas de conhecimento nos instrumentos, o que os levaram a sugerir a criação de novos vídeos e o acréscimo de outros itens a serem explorados nas trilhas.

Pode-se perceber pelos resultados da pesquisa que os recursos utilizados foram, de fato, eficientes como instrumentos de educomunicação. Segundo Higuchi e Azevedo (2004, p.65), a introdução dos conteúdos ambientais para estudantes deve ser feita de forma "criativa, motivadora $e$ eficaz". O vídeo conseguiu tanto prender a atenção dos espectadores, como aumentar de forma significativa a quantidade de respostas certas na pesquisa. Além disso, ele despertou a curiosidade dos alunos para o assunto, o que pode ser percebido com as perguntas sobre os temas abordados nos instrumentos.

No entanto, o vídeo não possibilita a experiência sensorial que a trilha possibilita. Apesar de a trilha ter um roteiro e os pontos predeterminados para serem destacados, existe ali uma ampla gama de sensações e itens a serem observados que não fizeram parte do planejamento. Guimarães (2006, s.p.) afirma que as trilhas são experiências "dinâmicas, participativas e colaborativas", dotadas de múltiplos estímulos sensoriais, que envolvem aspectos ligados à memória, afetividade, cognição, percepção, interpretação e valoração ambientais. Essas sensações e esse contato com a natureza despertam maior interesse nos estudantes do que a exibição de um conteúdo por meio de uma tela. Isso porque eles percebem que aquele conteúdo não é algo distante de suas realidades. O contato com o solo, as árvores, os cheiros, os sons e todos os demais elementos que compõem a trilha podem proporcionar uma experiência nova aos estudantes e assim o interesse em Revbea, São Paulo, V. 12, № 2: 79-95, 2017. 
repetir a atividade, e consequentemente, se importar com a conservação daquele fragmento florestal.

Os estudantes que participaram da trilha, cujos índices de acertos no questionário após a pesquisa não foram tão significativos, asseguraram ter tido uma experiência agradável durante a realização da atividade. Pode-se notar também que a atividade foi enriquecedora para despertar a curiosidade dos estudantes sobre questões ambientais em geral, tendo em vista a quantidade de perguntas feitas pelos alunos sobre assuntos da trilha não abordados nos questionários.

Conforme citado, os estudantes devem aprender sobre a natureza conhecendo-a no local no qual residem, valorizando a biodiversidade, os saberes e os personagens que estão inseridos naquele contexto. $O$ contato com o ambiente natural leva os estudantes a repensarem sua relação com a natureza, possibilitando a se entenderem como parte dela. Ou seja, a promoção da proximidade entre o estudante e a natureza desperta neles a reflexão para a conservação ambiental. Além disso, a experiência na trilha e os conhecimentos ali adquiridos podem perdurar por mais tempo na memória dos alunos pelo fato de envolver todos os sentidos e por ser presencial, enquanto os conteúdos adquiridos com o vídeo, se não relembrados, podem ser esquecidos por eles após certo tempo.

Outro ponto importante da realização dessa pesquisa é o encerramento do ciclo do processo comunicativo. Uma das etapas do processo comunicativo é o feedback, em que um dos agentes do processo comunicativo (comumente chamado de receptor) relata o que absorveu da comunicação emitida pelo outro agente (o emissor). Geralmente, ao utilizar os instrumentos de comunicação, o processo comunicativo fica incompleto, pois não há o retorno das mensagens repassadas. Portanto, a relevância é exatamente esta: relatar para aqueles que produziram a comunicação a resposta dada por aqueles que a ela tiveram acesso. No entanto, o processo comunicativo não se encerra com o feedback. Ele serve de base para que uma nova etapa do processo comunicativo seja iniciada, a partir da troca de informações entre ambos interlocutores. Isto é, a partir dos resultados dessa pesquisa, será possível fazer uso dos diversos instrumentos de educomunicação de forma melhorada, utilizando as características de cada um deles para tornar as ações educomunicacionais ainda mais proveitosas.

Ambos os instrumentos, apesar de cada um cumprir bem com seu papel como ferramentas de educomunicação, se utilizados em conjunto, podem ser muito mais eficazes para a sensibilização dos estudantes. Podem, portanto, ser produzidos para diferentes fins e utilizados por professores para complementar os conteúdos ensinados em sala de aula, tanto no ensino médio como nos diversos cursos oferecidos pela Universidade.

A eficácia do vídeo e da trilha como instrumentos de educomunicação foi comprovada. Apesar de o vídeo ter sido mais eficiente para aumentar a quantidade de respostas certas dos alunos, a atividade na trilha os despertou

revista brasileira educação ambiental 
para uma série de questões que foram além dos conteúdos exibidos nos instrumentos. Portanto, pode-se concluir que as atividades na trilha e no vídeo foram complementares, tendo um melhor resultado quando aplicadas em conjunto para o mesmo grupo de estudantes.

\section{Agradecimentos}

Às equipes do Centro de Ciências do Ambiente (CCA) da Ufam, da Escola Estadual Sólon de Lucena e da Banksia Films; aos professores que cederam tempo de aula para a realização da pesquisa e aos alunos e demais professores que participaram dela.

\section{Referências}

AZEVEDO, G.C.; HIGUCHI, M.I.G. Educação como processo na construção da cidadania ambiental. Revista Brasileira de Educação Ambiental. [on-line]. N 0. Brasília: Rede Brasileira de Educação Ambiental, 2004.

BOFF, L. Sustentabilidade: O que é - O que não é. Petrópolis: Vozes, 2012.

BRASIL. Ministério do Meio Ambiente. Secretaria de Articulação Institucional e Cidadania Ambiental. Programa Nacional de Educação Ambiental. Educomunicação socioambiental: comunicação popular e educação. Brasília: MMA, 2008.

CITELLI, A.O. Comunicação e educação: um olhar para a diversidade. In: CITELLI, A.O.; COSTA, M.C.C. (orgs). Educomunicação: construindo uma nova área do conhecimento, por. São Paulo: Paulinas, 2011.

CITELLI, A.O.; COSTA, M.C.C. (orgs). Educomunicação: construindo uma nova área do conhecimento, por. São Paulo: Paulinas, 2011.

ENGEL, G.I. Pesquisa-ação. Revista Educar. Curitiba. n. 16. 2000. Ed. UFPR.

FREIRE, P. Pedagogia da autonomia: Saberes necessários à prática educativa. São Paulo: Paz e Terra, 1996.

FRITZEN, R.I. Contribuições da trilha ecológica do canarinho à educação ambiental numa comunidade escolar - Porto Alegre: Pontifícia Universidade Católica do Rio Grande do Sul, Faculdade de Física, 2010.

FORTES, W.G Relações Públicas: processos, funções, tecnologia e estratégias. São Paulo: Summus, 2003.

GOERGEN, P. A comunicação nas faculdades de educação. In: KUNSCH, M.M.K. Comunicação e Educação: caminhos cruzados, por. São Paulo: INTERCOM/Loyola/AEC, 1986.

GUIMARÃES, S.T.L. Trilhas Interpretativas e Vivências na Natureza: reconhecendo e reencontrando nossos elos com a paisagem. Anais do o Congresso Brasileiro de Planejamento e Manejo de Trilhas. Rio de Janeiro: UERJ, 2006. Disponível em: http://migre.me/faruJ Acesso em: 14 jun. 2013. 
KUNSCH, M.M.K. (org). Comunicação e Educação: caminhos cruzados. São Paulo: 1986, INTERCOM/Loyola/AEC.

KUNSCH, M.M.K. Planejamento de Relações Públicas na Comunicação Integrada. São Paulo: Summus, 2003.

MANAUS. Decreto no 1.503 de 27 de março de 2012. Diário Oficial do Município. Disponível em http://migre.me/eo6il Acesso em 10 mar. 2013.

MARTÍN-BARBERO, J. Desafios culturais: da comunicação à educomunicação. In: CITELLI, A.O.; COSTA, M.C.C. (orgs). Educomunicação: construindo uma nova área do conhecimento, por. São Paulo: Paulinas, 2011.

MATAREZI, J. Despertando os sentidos da educação ambiental. Revista Educar, n. 27, p. 181-199. Curitiba: Editora UFPR, 2006.

MENGHINI, F.B. As trilhas interpretativas como recurso pedagógico: caminhos traçados para a educação ambiental. Itajaí: Universidade do Vale do Itajaí, Centro de Ciências Humanas e da Comunicação, 2005.

OROZCO-GÓMEZ, G. Comunicação, educação e novas tecnologias: tríade do século XXI. In: CITELLI, A.O.; COSTA, M.C.C. (orgs). Educomunicação: construindo uma nova área do conhecimento, por. São Paulo: Paulinas, 2011.

RAMOS, J.L.B. ¿Qué es el vídeo educativo? [online] Disponível em http://migre.me/fapl8 Acesso em 14 jun. 2013. Universidad Politécnica de Madrid. Madrid. s.d.

SANTOS, M.C. et al. Trilhas interpretativas como instrumento de interpretação, sensibilização e educação ambiental na Apae de Erechim/RS. Vivências: Revista Eletrônica de Extensão da URI. Vol. 7, 2011.

SOARES, I.O. Educomunicação: um campo de mediações. In: CITELLI, A.O.; COSTA, M.C.C. (orgs). Educomunicação: construindo uma nova área do conhecimento, por. São Paulo: Paulinas, 2011.

TELG, R. Producing na Educational Video. [online] Disponível em http://edis.ifas.ufl.edu/wc024 Acesso em 14 jun. 2013 University of Florida. Gainesville. 1999

TRIVIÑOS, A.N.S. Introdução à pesquisa em ciências sociais: a pesquisa qualitativa em educação. 1 ed. São Paulo: Atlas, 2012.

WOHLGEMUTH, J. Vídeo educativo: Uma pedagogia audiovisual. Brasília: Editora Senac - DF, 2005. 